\title{
Composition of Mix Species Foraging Flocks of Birds in Riverstan of Montane Region, Sri Lanka
}

\author{
W.G.D.D.M. Shermila* and S. Wikramasinghe \\ Department of Biological Science, Rajarata University of Sri Lanka, Mihinthale
}

Date Received: 21-11-2012 Date Accepted: 23-02-2013

\begin{abstract}
Montane zone mixed-species bird flock system is distinct from that of low-land wet zone of Sri Lanka, although some species are present in both systems. The present study identified the mixed species flocks of birds in Riverstan at Knuckles Region, Sri Lanka. Monthly transect counts and opportunistic observations were made between January and May, 2012. A total of 78 flocks and 27 bird species were encountered at Riverstan during the study period. The flock size varied between 2 to 13 species and 4 to 58 individuals. The mean number of species per flock was $6.03 \pm 2.25$ and the mean number of individuals in a flock was $18.41 \pm 9.87$. The flock size was positively correlated with the number of species present $(\mathrm{r}=0.756, \mathrm{P}<0.05)$. Grey-headed Canary Flycatcher was the most abundant species (mean $2.68 \pm 1.02$ birds per flocks) while Sri Lanka White-eye was the most frequent species (mean 5.69 \pm 3.92 birds per flocks). Grey-headed Canary Flycatcher and Sri Lanka Scimitar-babbler were the nuclear species in Riverstan. The leading species were Sri Lanka white-eye and Sri Lanka Yellow-eared Bulbul. Different bird species used different heights within flocks.
\end{abstract}

Keywords: Mixed-species flock, Nuclear species, Abundance, Foraging flocks

\section{Introduction}

Mixed-species flocks (MSF) are an important form of the social organization of birds throughout the world, particularly in the forested tropics (Thiollay, 1999). The mixed-species flocks were characteristic of all forest edge habitats, and their composition varies with the elevation and habitat. Nuclear species mainly differ with the elevation and habitat in the northern flank of the Knuckles Range (Sriyani et al., 2005). Montane zone flock system is distinct from that of low land wet zone of Sri Lanka, although some species are present in both systems. The studies on flocking behaviour in Sri Lanka have been predominantly conducted in the low land wet zone forests. Hence, relatively little information is available on flocking behaviour in other habitat types in Sri Lanka and it is important to have a working knowledge of the structure, dynamics and special organization of MSF to assess the status of MSF to formulate suitable conservation strategies for MSF. Therefore, the present study was carried out to identify the flock composition, vertical distribution pattern, habitat preference of the flocking species in MSF at Riverstan of Montane region.

*Correspondence: dayani_weragoda@yahoo.com Tel: +94774401636

ISSN 2235-9370 Print / ISSN 2235-9362 Online C2013 University of Sri Jayewardenepura 


\section{Study area}

The study was conducted Riverstan montane region (Figure 1.) $\left(7^{\circ} 32^{\prime} \mathrm{N}, 80^{\circ} 44^{\prime} \mathrm{W}, 950 \mathrm{~m}\right)$ located in the central province of Sri Lanka. The study area is $6 \mathrm{Km}^{2}$ in area and encompasses altitudes ranging $900 \mathrm{~m}$ to $1100 \mathrm{~m}$ (Herath and Priyantha, 2003). The vegetation is predominantly sub-montane forests with wet phase at higher altitude and dry phase in lower altitude. This forest retains a multilayered and the higher of the forest is approximately $15 \mathrm{~m}$ from ground to top canopy. The study area consisted of secondary forest; understory vegetation is generally dense cover with cardamom cultivation.

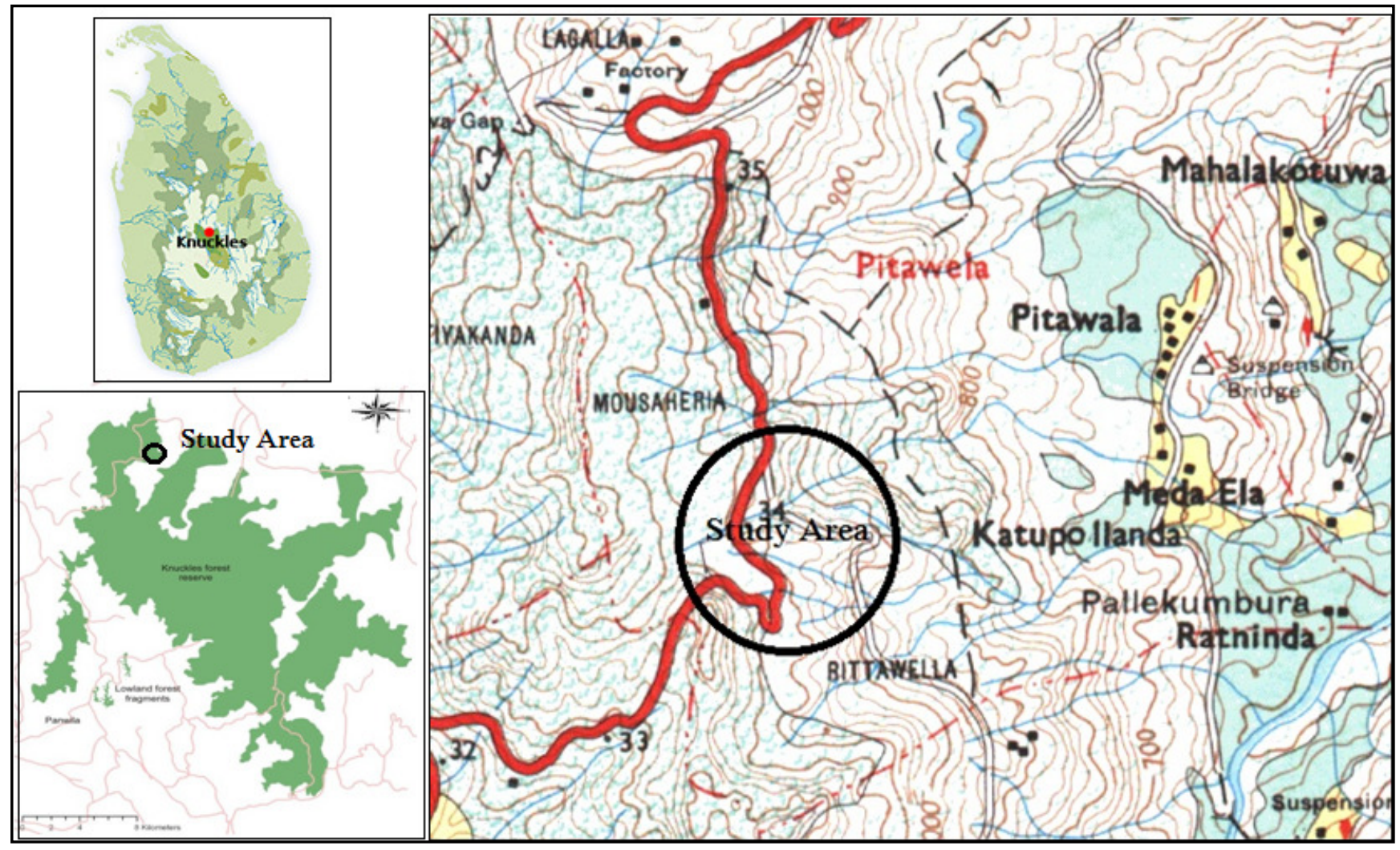

Figure 1: Map of the study site

\section{Methodology}

\subsection{Data collection}

Mixed-species flocks were sampled on the established line transects and opportunistically along pre-determined transect daily two weeks per month starting from January to May 2012. A distance of $200 \mathrm{~m}$ maintain between two flocks during the counting to avoid the repeated counts. While walking along transects the mixed-species flocks were observed and the GPS coordinates at these points were recorded. As soon as a mixed species flock was met, the vegetation was scanned thoroughly from the canopy layer down to the forest understory so as to identify all flock participants. When encountered on transects, for each mixed-species flock, species composition, as well as the cluster size, detection azimuth and detection distance for each species cluster in the mixed-species flock were recorded. These data were incorporated during species abundance estimation. During opportunistic sampling, the species composition of the mixed-species flock and the group size of each participating species were recorded. For the species observed, classified them according to their occurrence in MSF as: core (nuclear, leader) (present in $40 \%$ or more of the MFSs), regular (common) (more than 11\%), and occasional (rare) $(<11 \%)$ following Machado (1999). 


\subsection{Data analysis}

The spearman correlation test was done to determine the correlation between number of species and number of individuals in a flock at Riverstan. Multivariate analysis was used to plot the Tree-cluster dendrogram to determine the degree of association between height of the flock species and feeding categories of the different species in the flocks at two sites. This is derived from a matrix based on the degree of structural overlap for the species (Bell, 1981). This shows which species are most closely associated with each other in different habitats within the site. The computer program Statistic version 16 was used for the plotting of the dendrogram.

\section{Results}

\subsection{Flock composition}

A total of 78 flocks and 27 flocking species were encountered at Riverstan during the study period (Table 1). Out of 27 flocking species 19 residents, 7 endemics and 1 migrant species were observed in the study site. One mammal, the Jungle squirrel (Funambulus sublineatus obscures) was common in all flocks. Most of the flocks (19.22\%) at Riverstan consisted of six species. Mean species richness (derived from a raw count of the number of species) was 6.03 species (range from 2 to 13 species. $\mathrm{SD}=2.25$ ). The mean number of individuals in these flocks was 18.41 (range from 4 to $58, \mathrm{SD}=9.87$ ).

Over $50 \%$ of the flocks had 11 to 20 individuals while flocks with 41 to 50 individuals were few (1.28\%) (Table2). Grey-headed Canary Flycatcher (Culicicapa ceylonensis) was the most frequent species (mean 2.68 \pm 1.02 birds per flocks) encountered in 63 flocks while Sri Lanka White-eye (Zosterops ceylonensis) was the most abundant species (mean 5.69 \pm 3.92 birds per flocks) encountered with 269 individuals and 52 flocks. The flock size was positively correlated with the number of species present $(\mathrm{r}=$ $0.756, p=0.00)$ (Figure 2.)

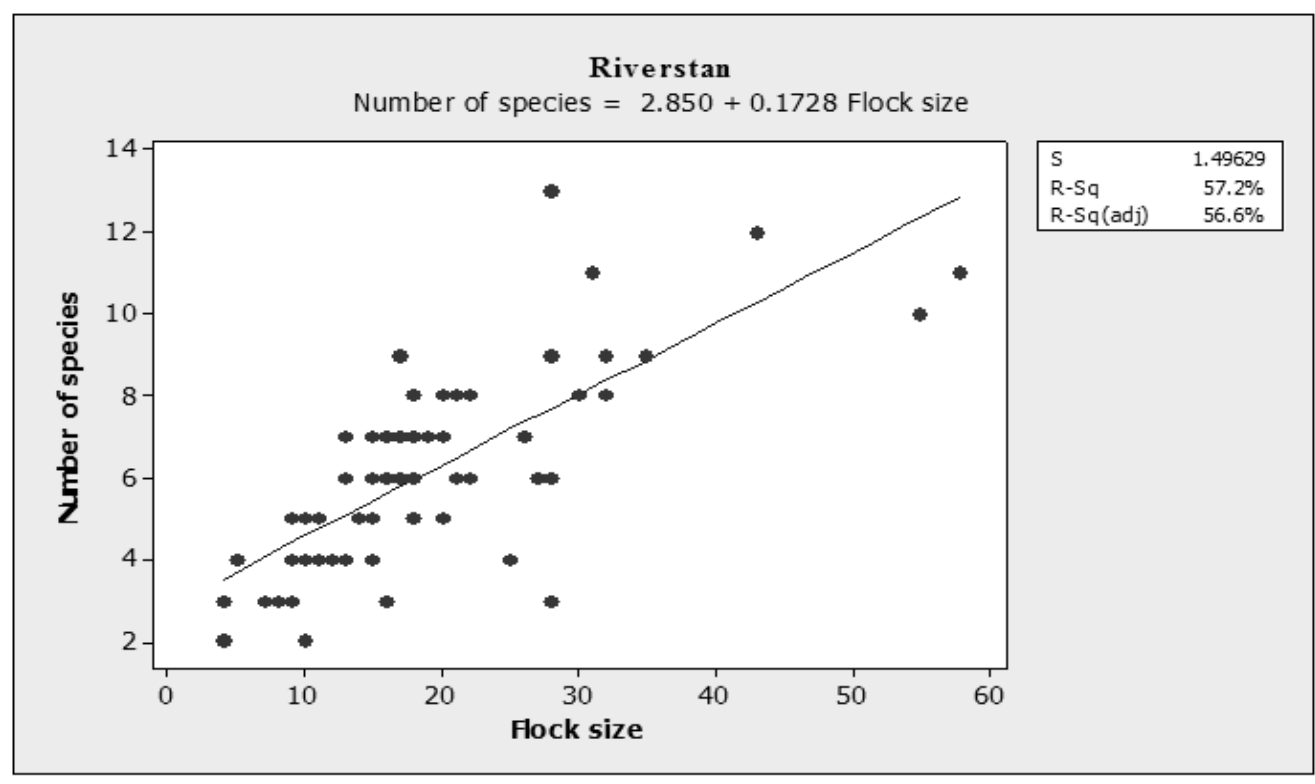

Figure 2: Correlation between number of species and flock size at Riverstan 
Table 1: The number of Flocking species detected in 78 flocks in Riverstan $(\mathrm{N}=78)$

\begin{tabular}{|c|c|c|c|c|}
\hline Name of the species & Category & $\begin{array}{l}\text { Mean of the } \\
\text { birds }\end{array}$ & $\begin{array}{l}\text { Frequency in } \\
\text { flocks }\end{array}$ & $\begin{array}{l}\text { Relative } \\
\text { Abundance }\end{array}$ \\
\hline $\begin{array}{l}\text { 1.Oriental white-eye }{ }^{\mathrm{BR}} \text { (OWE) } \\
\text { Zosterops palpebrosa }\end{array}$ & $\mathrm{R}$ & $6.00 \pm 6.96$ & 17.95 & 5.87 \\
\hline $\begin{array}{l}\text { Zosterops palpebrosa } \\
\text { 2.Sri Lanka white eye }{ }^{\mathrm{E}} \quad \text { (SLWE) }\end{array}$ & $\mathrm{L}$ & $5.69 \pm 3.92$ & 66.67 & 20.67 \\
\hline $\begin{array}{l}\text { Zosterops ceylonensis } \\
\text { 3.Velvet- fronted Nuthatch }{ }^{\mathrm{BR}} \quad \text { (VFNH) } \\
\text { Sitta frontalis }\end{array}$ & $\mathrm{R}$ & $3.87 \pm 1.99$ & 48.72 & 10.27 \\
\hline $\begin{array}{l}\text { 4.Sri Lanka Yellow- eared Bulbul }{ }^{\mathrm{E}} \text { (YEBB) } \\
\text { Pycnonotus penicillatus }\end{array}$ & $\mathrm{L}$ & $3.81 \pm 2.85$ & 53.85 & 11.17 \\
\hline $\begin{array}{l}\text { 5.Jerdon's leafbird }{ }^{\mathrm{BR}}(\mathrm{JLB}) \\
\text { Chloropsis aurifrons }\end{array}$ & $\mathrm{O}$ & $3.50 \pm 2.08$ & 5.13 & 0.98 \\
\hline $\begin{array}{l}\text { 6.Black Bulbul }{ }^{\mathrm{BR}} \quad \text { (BBB) } \\
\text { Hypsipetes leucocephalus humii }\end{array}$ & $\mathrm{R}$ & $3.13 \pm 1.12$ & 30.77 & 5.24 \\
\hline $\begin{array}{l}\text { 7.Purple -rumped sunbird }{ }^{\mathrm{BR}} \text { (PRSB) } \\
\text { Nectarinia zeylonica zeylonica }\end{array}$ & $\mathrm{O}$ & $3.00 \pm 2.83$ & 2.56 & 0.42 \\
\hline $\begin{array}{l}\text { 8. Sri Lanka Scimittar Babbler }{ }^{\mathrm{E}} \text { (SB) Pomatorhinus } \\
\text { horsfieldii }\end{array}$ & $\mathrm{N}$ & $2.86 \pm 0.98$ & 47.44 & 7.40 \\
\hline $\begin{array}{l}\text { 9.Dark fronted Babbler }{ }^{\mathrm{BR}}(\mathrm{DFB}) \\
\text { Rhopocichla atriceps }\end{array}$ & $\mathrm{O}$ & $2.78 \pm 1.20$ & 9.54 & 1.75 \\
\hline $\begin{array}{l}\text { 10.Grey- headed Canary Flycatcher }{ }^{\mathrm{BR}} \text { (GHCFC) } \\
\text { Culicicapa ceylonensis }\end{array}$ & $\mathrm{N}$ & $2.68 \pm 1.03$ & 80.77 & 11.80 \\
\hline $\begin{array}{l}\text { 11.Flame Minivet }{ }^{\mathrm{BR}} \quad(\mathrm{FM}) \\
\text { Pericrocotus cinnamomeus }\end{array}$ & $\mathrm{R}$ & $2.55 \pm 1.04$ & 14.10 & 1.96 \\
\hline $\begin{array}{l}\text { 12.Brown-capped Babbler }{ }^{\mathrm{E}} \text { (BCBb) } \\
\text { Pellorneum fuscocapillum }\end{array}$ & $\mathrm{O}$ & $2.33 \pm 0.58$ & 3.85 & 0.49 \\
\hline $\begin{array}{l}\text { 13.Tawny-bellied Babbler }{ }^{\mathrm{BR}}(\mathrm{TBBb}) \\
\text { Dumetia hyperythra phillipsi }\end{array}$ & $\mathrm{O}$ & $2.33 \pm 0.58$ & 3.85 & 0.49 \\
\hline $\begin{array}{l}\text { 14.Bar-winged flycatcher-shrike }{ }^{\mathrm{BR}} \text { (BWFCS) } \\
\text { Hemipes picatus leggei }\end{array}$ & $\mathrm{R}$ & $2.29 \pm 0.69$ & 30.77 & 3.84 \\
\hline $\begin{array}{l}\text { 15. Small Minivet }{ }^{\mathrm{BR}}(\mathrm{SM}) \\
\text { Pericrocotus cinnamomeus }\end{array}$ & $\mathrm{O}$ & $2.25 \pm 0.50$ & 5.13 & 0.63 \\
\hline $\begin{array}{l}\text { 16.Grate Tit }{ }^{\mathrm{BR}}(\mathrm{GT}) \\
\text { Parus major }\end{array}$ & $\mathrm{R}$ & $2.15 \pm 0.71$ & 50.00 & 5.87 \\
\hline $\begin{array}{l}\text { 17.Green Tree Warble }{ }^{\mathrm{M}}(\mathrm{GTW}) \\
\text { Phylloscopus trochiloides viridanus }\end{array}$ & $\mathrm{O}$ & $2.14 \pm 0.38$ & 8.97 & 1.05 \\
\hline $\begin{array}{l}\text { 18.Dull-blue flycatcher }{ }^{\mathrm{E}} \text { (DBFC) } \\
\text { Eumyias sordid }\end{array}$ & $\mathrm{R}$ & $2.11 \pm 0.38$ & 11.54 & 1.33 \\
\hline $\begin{array}{l}\text { 19. White- browed Bulbul }{ }^{\mathrm{BR}} \text { (WBBB) } \\
\text { Pycnonotus luteolus insulae }\end{array}$ & $\mathrm{O}$ & $2.00 \pm 0.38$ & 1.28 & 0.14 \\
\hline $\begin{array}{l}\text { 20. Yellow- fronted Barbet }{ }^{\mathrm{BR}} \text { (YFB) } \\
\text { Megalaima flavifrons }\end{array}$ & $\mathrm{R}$ & $1.94 \pm 0.38$ & 23.08 & 2.44 \\
\hline $\begin{array}{l}\text { 21. White- bellied Drongo }{ }^{\mathrm{BR}} \text { (WBD) } \\
\text { Dicrurus caerulescenns leucopygialis }\end{array}$ & $\mathrm{O}$ & $1.67 \pm 1.15$ & 3.85 & 0.35 \\
\hline $\begin{array}{l}\text { 22.Long-billed sunbird }{ }^{\mathrm{BR}} \text { (LBSB) } \\
\text { Nectarinia lotenia lotenia }\end{array}$ & $\mathrm{R}$ & $1.53 \pm 0.52$ & 19.23 & 1.61 \\
\hline $\begin{array}{l}\text { 23.Common Iora }{ }^{\mathrm{BR}}(\mathrm{CI}) \\
\text { Aegithina tiphia }\end{array}$ & $\mathrm{O}$ & $1.50 \pm 1.07$ & 10.00 & 0.84 \\
\hline $\begin{array}{l}\text { 25. Malabar Trogon }{ }^{\mathrm{BR}} \quad \text { (MT) } \\
\text { Harpactes fasciatus }\end{array}$ & $\mathrm{R}$ & $1.22 \pm 0.44$ & 11.54 & 0.77 \\
\hline $\begin{array}{l}\text { 26.Black - napped Monarch }{ }^{\mathrm{BR}}(\mathrm{BNM}) \\
\text { Hypothymis azurea ceylonensis }\end{array}$ & $\mathrm{R}$ & $1.18 \pm 0.40$ & 14.10 & 0.91 \\
\hline $\begin{array}{l}\text { 27.Sri Lanka Spot winged Thrush }{ }^{\mathrm{E}} \text { (SLSWT) } \\
\text { Zoothera spilopter }\end{array}$ & $\mathrm{O}$ & $1.00 \pm 0.00$ & 2.56 & 0.14 \\
\hline
\end{tabular}

BR - Breeding Resident, E - Endemic, M-Migrant 
$N$ - Nuclear, L-Lead, R-Regular, O-Occasiona

Table 2: Percentages of number of species per flocks and number of individuals per flock at Riverstan

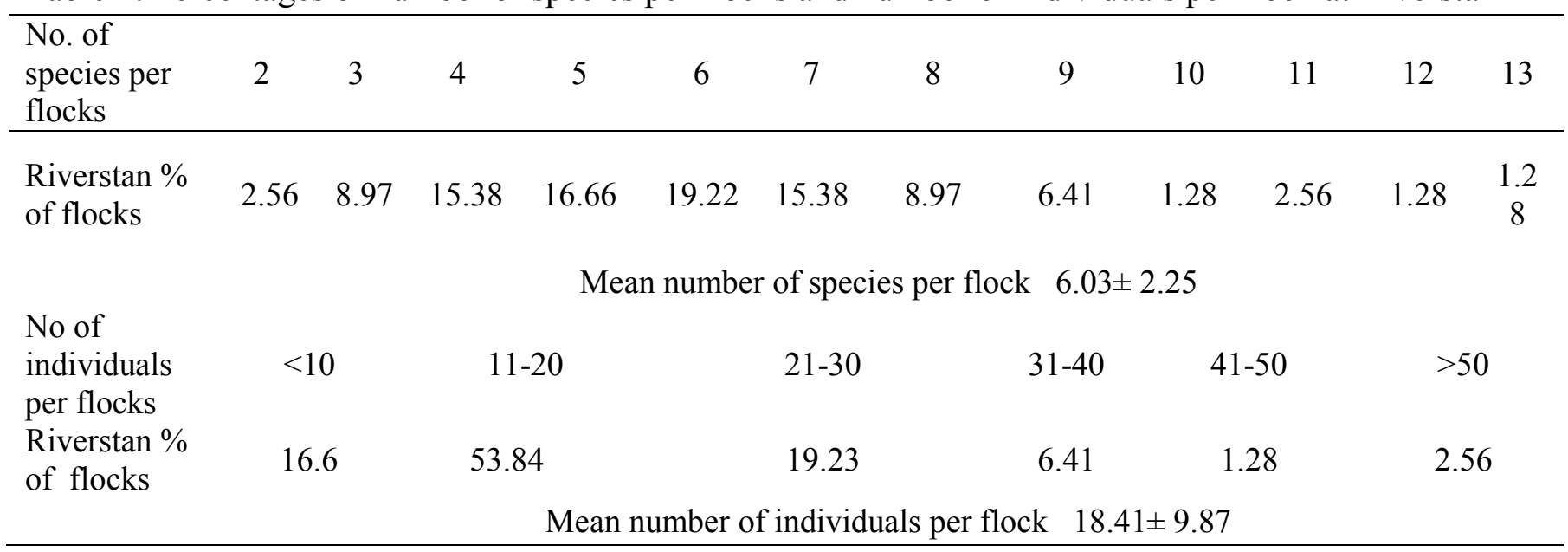

\subsection{Flock organization}

Flocking bird species were categorized as Nuclear, Lead, Regular, and Occasional (Table 1). Out of the 27 species, 4 species were core participant, 11 species were regular attendants and 11 species were irregular attendants (Figure 3). Grey-headed Canary Flycatcher and Sri Lanka Scimitar Babbler were the nuclear species in Riverstan and they contributed to form flocks. Among these two species, Grey-headed Canary Flycatcher was the most prominent nuclear species at Riverstan. Sri Lanka Scimitar Babbler formed small mixed-species foraging flocks. They formed flocks in the absence of the Grey Headed Canary Flycatcher. The leading species were far ahead of the followers and they were Sri Lanka whiteeye and Sri Lanka Yellow-eared Bulbul. It was observed that more than $60 \%$ flocks were lead by Sri Lanka white eye. Black Bulbul contributed to give alarm calls in the flock.

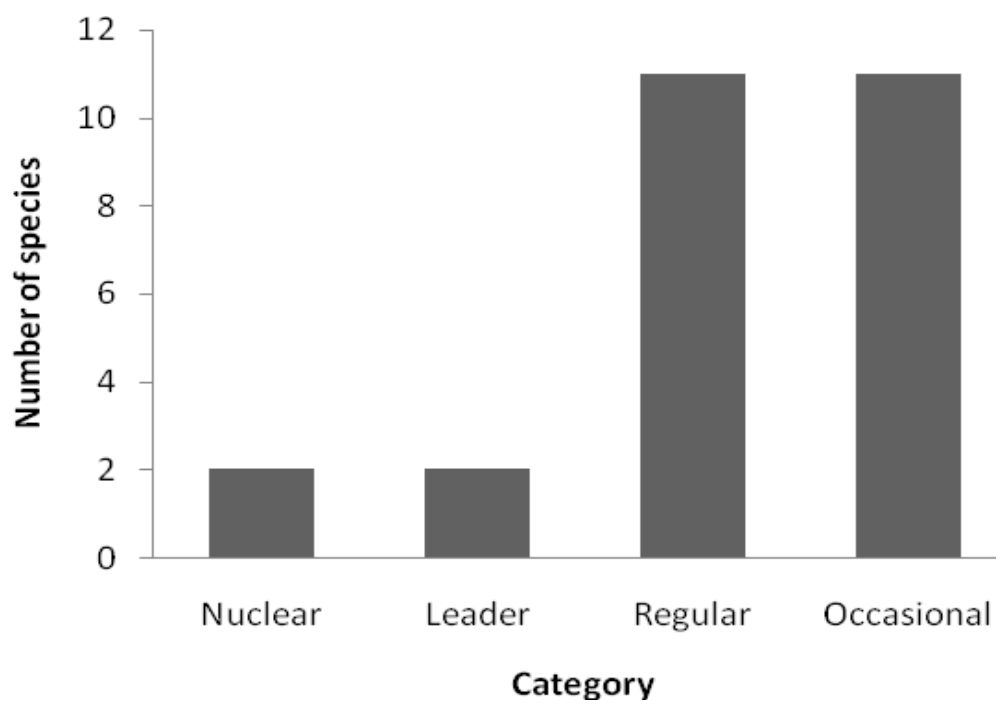

Figure 3: Number of species in flock participation according to the role

\subsection{Niches occupancy of flocking species}

Bird species in the flock had different foraging niches. The degree of association between height of the flock species and feeding categories of different species in the flocks were shown in figure 5 . Structural overlap values between several species were high and these were grouped together. Flocks 
consisted of two major groups (A and B) in foraging flocks. Group A had bird species which used canopy and sub-canopy as feeding niche. This group was divided mainly into two sub groups. Ten bird species were clustered under group $\mathrm{i}$ and they fed on upper layer of the vegetation (Canopy and Upper sub canopy). Group i was divided into two clusters. Among these two clusters Black Bulbul, Yellow- fronted Barbet, Flame Minivet, Jerdon's leafbird, Small Minivet were under one cluster and they usually used canopy as foraging level. The other cluster under group i, consisted of Bar-winged flycatcher-shrike, Oriental white-eye, Sri Lanka white eye, Common Iora, Sri Lanka Yellow-eared Bulbul and these bird species forage on upper level of sub canopy. Under this category structural overlap value of Sri Lanka Yellow-eared Bulbul was less because they fed on selected tree species in between sub canopy to under story. Group ii consisted of ten bird species. Under this group the structural overlap among Grey- headed Canary Flycatcher, Velvet- fronted Nuthatch, and Green Tree Warbler was higher because they feed on canopy to understory. In addition to that structural overlap was observed between Grate Tit and Dull-blue flycatcher. Long-billed sunbird had less structural overlap among group ii bird species because it was used a different foraging height.

Group B consisted of five flocking species. These species used understory to ground level as a feeding height. Dark fronted Babbler and Sri Lanka Scimittar Babbler were clustered together under group B because they use ground to sub canopy as a feeding niche. Brown-capped Babbler, Sri Lanka Spot winged Thrush and Tawny-bellied Babbler were clustered under one group and structural overlap among these birds were higher because they fed on ground and understory. The highest percentage of flocking birds used the sub canopy layer as their foraging level. According to the feeding guild of birds, foliage and flower gleaners and salliers represented high percentage within flocks (Figure 4). This is because of insectivores were high in flocks.

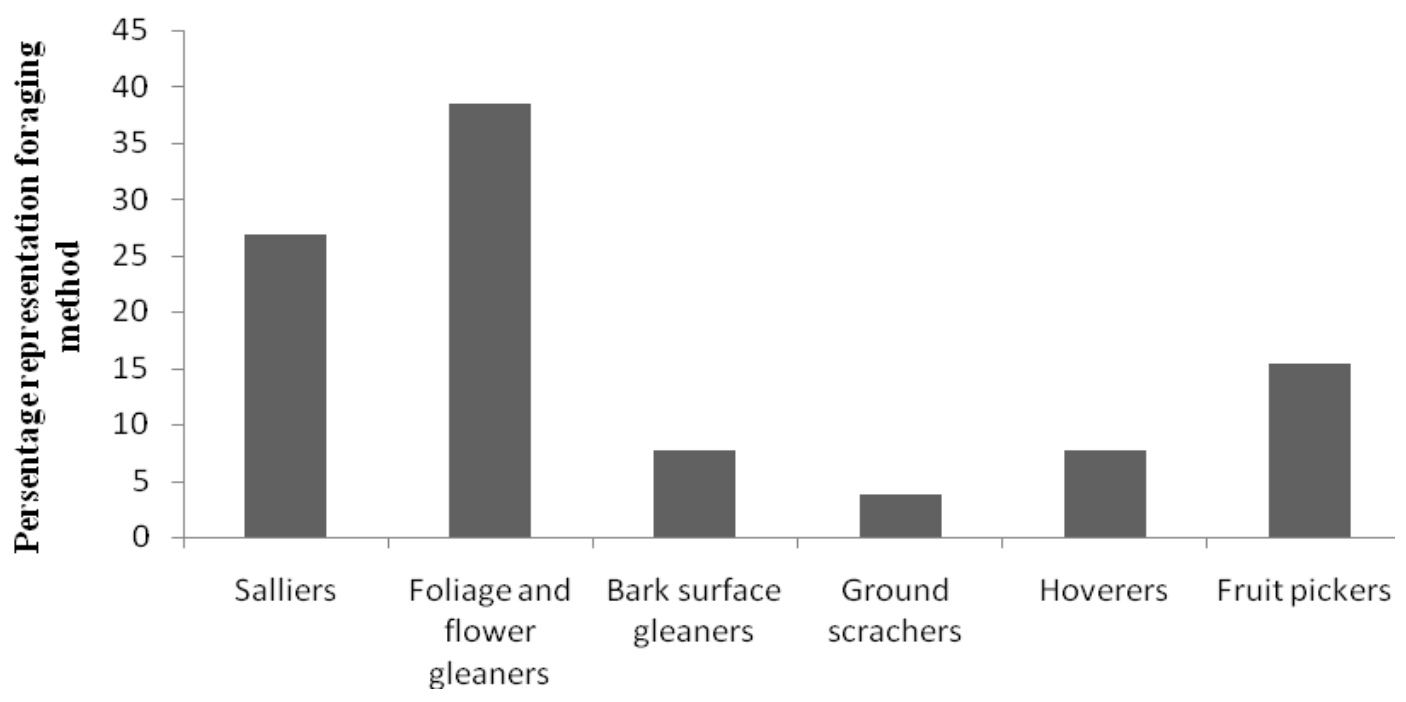

Figure 4: Feeding guilds of flocking species at Riverstan

\section{Discussion}

Montane zone flock system is distinct from that of the low land wet zone of Sri Lanka, although same species are represented in both systems (Kotagama and Goodale, 2004). Singharaja flocks are always included Orange-billed Babbler (Turdoides rufecens), Greater Racket-tailed Drongo (Dicrurus paradiseus) but Riverstan flocks always contain Grey- headed Canary Flycatcher, Sri Lanka white eye, Sri Lanka Yellow-eared Bulbul and Sri Lanka Scimitar Babbler. 


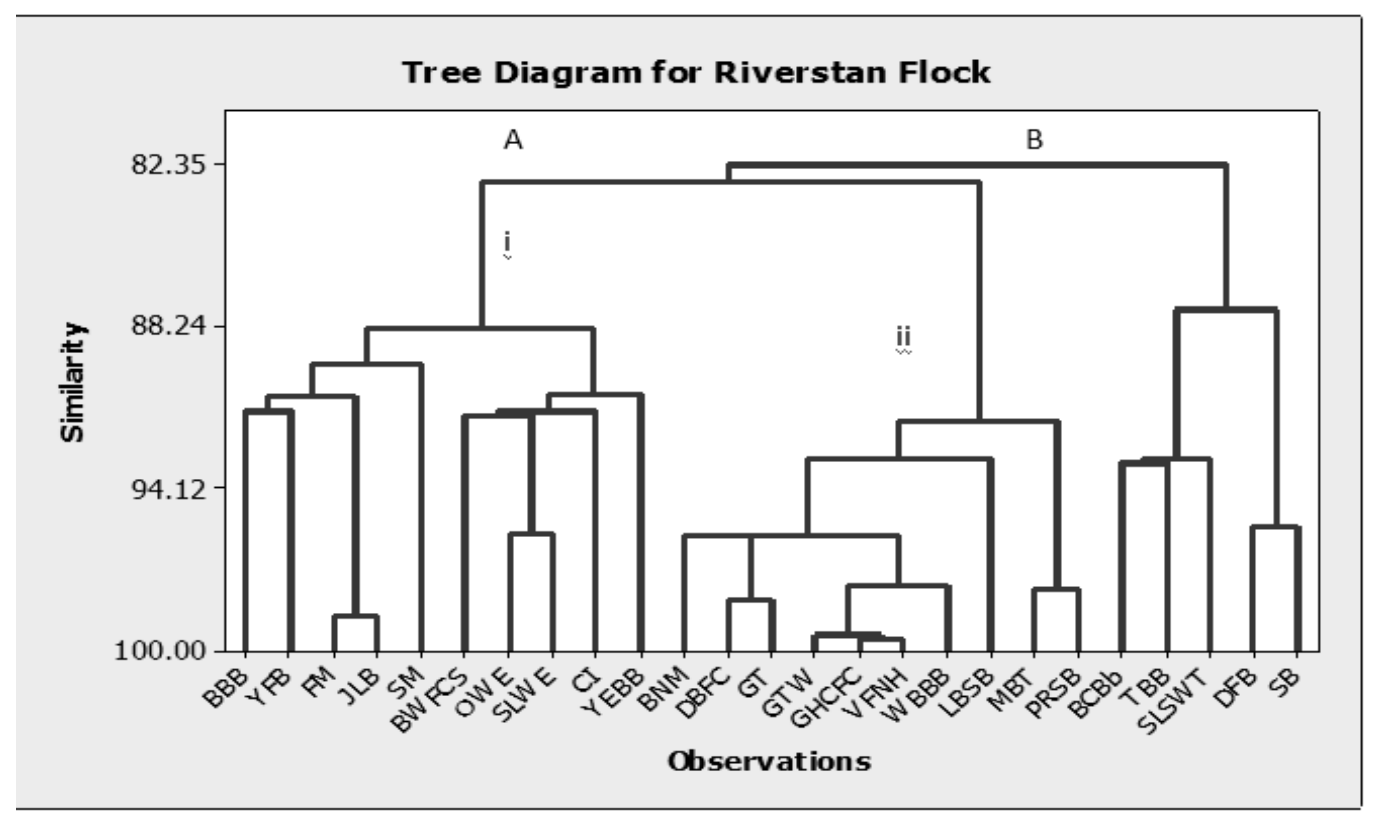

Figure 5: Dendrogram of relationship of foraging height of species in Riverstan flocks

Among these birds, Grey- headed Canary Flycatcher and Sri Lanka Scimitar Babbler contributed to form Riverstan flocks. The movement, especially vocalizations made other birds easy to follow them. Grey-headed Canary Flycatcher was the most prominent nuclear species at Riverstan and it formed 3-10 birds. Sri Lanka Scimitar Babbler form small mixed-species foraging flocks and they form flocks when Gray Headed Canary Flycatcher is absent. Black Bulbul and Jungle squirrel give alarm calls.

The relative configurations of territories of flock participants have a major impact on flock membership and stability. As a flock moves through its range, species join and leave the group within the constraints of their own home range (Powell, 1985). Dark fronted Babbler was a territorial bird and they joined with the flock only in their territory. Sri Lanka Spot winged Thrush (Zoothera spiloptera) joined to flocks in law frequency (2.86) and moved few distance with the flocks.

The flock size was positively correlated with the number of species present at Riverstan. According to Powell (1985), the structure and the individual composition of mixed flocks are generally highly stable. Flocks are composed primarily of one pair sometimes with young of each species to reduce predation as well as interspecies competition. Therefore, flock size is highly positively correlated with the number of species present. The cluster results clearly showed that the difference in utilization of vertical strata is an important factor contributing to niche differentiation within the study area. The foraging assemblage of mixed feeders, insectivores reflect the availability of food resources in different strata. Black Bulbul, Yellow- fronted Barbet, Jerdon's leafbird, Sri Lanka Hanging parakeet were clustered under same main cluster. Because they mainly fed on fruits and insects which were available in canopy level. This is generally considered to have largely overlapping food niches because they all feed on fruit at the same foraging sites. Grimmett (1998) have explained that different species harvest resources from the same species of fruiting tree in different ways, to reduce overlap. Overlap in a food niche may also result from specialization on arthropods that are flushed by a flock. Grey- headed Canary Flycatcher, Velvetfronted Nuthatch, Grate Tit, Common Iora fed on insects in the sub canopy. Although it is considered that the food niches of these insectivores are overlapping, the degree of overlapping is less than expected due to the difference on feeding methods among them (Figure 4.). Gray-headed Canary flycatcher was aerial 
sallies for insects while Velvet- fronted Nuthatch was bark surface gleaners. Grate Tit and Common Iora captured insects by gleaning among the branches for insect.

Insectivore participation in flocks was higher than that of omnivore and nectarivores at both sites. Therefore, percentage of salling, foliage and flower gleaning methods were higher than other feeding methods. All flycatchers which participated in flocks were salliers meanwhile Black Bulbul, Black napped Monarch, Forest Wagtail, Malabar Trogon showed salling feeding method. Grate Tit, Common Iora, Jerdon's leafbird, Sri Lanka white eye, Oriental white-eye, Sri Lanka Hanging parakeet, Black headed oriole were main foliage and flower gleaners. Among them Sri Lanka white eye and Oriental white-eye mostly preferred to feed on insects in the flowers of epiphytes. Sri Lanka Scimittar Babbler, Velvet- fronted Nuthatch, White-rumped Shama were the bark surface gleaners. Sri Lanka Spot Winged Thrush, Brown-capped Babbler was ground scratchers and sunbirds were hoverers. Yellow- fronted Barbet, Sri Lanka Yellow-eared Bulbul, showed fruit picking.

As shown above, bird species associated with mixed-species foraging bird flocks have different kinds of feeding methods and feeding guilds. These differences among bird species permit more systematic resource harvesting, reduce interspecific aggression, or facilitate reduction of niche overlapping (Austin and Smith, 1972).

Mixed-species bird flocking was common phenomena in the Knuckles region. Riverstan flocks contained 19 residents, 7 endemics, 1 migrant species and threatened species. As an example, Sri Lanka Yellow-eared Bulbul (Pycnonotus penicillatus) is one of the nearly threatened and endemic species within a flock. Most of the endemic flocking bird species had narrow to restricted altitudinal ranges; and were exclusively dependent on primary forest and understory micro-habitats. Sri Lanka Spot winged Thrush (Zoothera spiloptera) was limited to undisturbed and understory micro-habitats while Sri Lanka Yelloweared Bulbul was limited to high altitude. Therefore, it is important to conserve their native habitats and conservation actions should be taken to ensure their future stability.

Some habitats have a high number of species that form mixed species flocks and should be given top priority in conservation decisions. It is important to maintain habitat heterogeneity (e.g., closed canopy cover and high density of trees) as it is critical for the preservation of mixed species flock richness. The nuclear species play an important role within a flock. It is important to have knowledge about those species to take conservation action and conserve them and awareness programs should conduct to increase the interest on mixed species foraging flocks among the people and through this ensure their conservation status. Visitor entrance affects the flocking behaviour in many ways. Therefore, it is important to limit the visitor entrance where the flocking tendency is high. Mixed-species foraging flocks give natural beauty to the nature as well as help to keep the forest ecosystem more stable. Therefore, it is important to protect the bird community.

\section{Conclusion}

Among the 78 flocks 27 flocking species were recorded at Riverstan during the study period. Two nuclear species contributed to form MSF at Riverstan such as Grey-headed Canary Flycatcher and Sri Lanka Scimitar Babbler while Sri Lanka white eye and Sri Lanka Yellow-eared Bulbul lead flocks. Black Bulbul and Jungle squirrel gave alarm calls in the flock.

Bird species in the flock used different height rangers when they were feeding and moving. There were some structural overlapping foraging niches among bird species within flocks. But, the structural overlapping was reduced because bird species in same strata used different foraging gilds and foraging techniques. There were positive correlation between the flock size and the number of species present at Riverstan $(\mathrm{r}=0.756, \mathrm{P}=0.00)$, this is because to reduce inter-species competition. 
There are several threats for mixed-species flocks. Visitor entrance, habitat modification, forest fires and Illegal logging were major threats which are identified. Therefore, conservation action should be taken to conserve MSF and ensure their survival.

\section{Acknowledgement}

The authors wish to extend their gratitude to Prof. S.W. Kotagama for the guidance, Mr. Supun Wellappuliarachchi, Mr. Duminda S.B. Disanayake, Mr. Dilum Prebath, Miss. Chaya Sarathchandra for assisting in the field work, and Mr. Ranjan Dissanayake, Miss.Nethma Thabru and Miss. S.R.Sameranayake for their assistance in Statistical analysis of the project. A special thank is also due for Mahalakotuwa villagers for their support during the project.

\section{References}

Austin, G. T., E. L. Smith., 1972. Winter foraging ecology of mixed insectivorous bird flocks in oak woodland in southern Arizona. Condor 74:17-24.

Bell, H.L., 1981. A bird community of Lowland Rainforest in New Guinea mixed species feeding flocks. EMU (82): 143-162

Grimmett, R., Inskipp, T., Inskipp, C., 1998. Birds of the Indian Subcontinent. Oxford University Press, Delhi

Heart, T.R., Priyantha, R, 2003. An Illustreted Guide to the Fern Flora of Knuckles conservation area Sri Lanka, Rajarata University of Sri Lanka. ISBN: 955-99116-0-0

Kotagama, S.W., Googale, E., 2004. The composition and the spatial organization of mixed-species flocks in a Sri Lanka rainforest. Forktial 20, 63-70.

Machado, C.G., 1999. Mixed flocks of birds in Atlantic Rain Forest in Serra de Paranapiacaba, southeastern Brazil, Revista Brasileira de Biologia 59(1): 75-85.

Powell, G. V. N., 1985. Sociobiology and adaptive significance of interspecific foraging flocks in the Neotropics. Ornithol. Monogr. 36: 713_732.

Sriyani, W.M., Padmalal, U.K.G.K. and Kotagama, S.W., 2005. A study on Mixed species birds flocks of sub montane wet evergreen forest in the Northern Flank of the Knuckles Region in Sri Lanka. Lyriocephalus, 6 (1-2): 277-284.

Thiollay, J.-M., 1999. Frequency of mixed-species flocking in tropical forest birds and correlates of predation risk: an intertropical comparison. J. Avian Biol. 30: 282_294. 